\title{
Flowering in Persian walnut: patterns of gene expression during flower development
}

\author{
Amin Hassankhah ${ }^{1}$, Majid Rahemi ${ }^{2}$, Hossein Ramshini ${ }^{3}$, Saadat Sarikhani ${ }^{4^{*}}$ and Kourosh Vahdati $5^{*}$
}

\begin{abstract}
Background: Flower development and sufficient fruit set are important parameters with respect to walnut yield. Knowledge about flowering genes of fruit trees can help to conduct better molecular breeding programs. Therefore, this study was carried out to investigate the expression pattern of some flowering genes (FT, SOC1, CAL, LFY and TFL1) in Persian walnut (CV. Chandler) during the growing season and winter dormancy.

Results: The results showed that walnut flower induction and initiation in Shahmirzad, Iran occurred in early June and late September, respectively. After meeting chilling and heat requirement, flower differentiation and anthesis occurred in late-March and mid-April to early-May, respectively. Study of flowering gene expression showed that the expression of the FT gene increased in three stages including before breaking of bud dormancy, from late March to late April (coincided with flower differentiation and anthesis) and from late May to mid-June (coincided with flower induction). Like FT, the expression of SOCl gene increased during flower induction and initiation (midMay to early-August) as well as flower anthesis (mid-April to early-May). LFY and CAL genes as floral meristem identity genes are activated by FT and SOC1 genes. In contrast with flowering stimulus genes, TFL1 showed overexpression during winter dormancy which prevented flowering.

Conclusion: The expression of FT gene activated downstream floral meristem identity genes including SOC1, CAL and LFY which consequently led to release bud dormancy as well as flower anthesis and induction. Also, TFL 1 as a flowering inhibitor gene in walnut showed overexpression during the bud dormancy. Chilling accumulation reduced TFL1 gene expression and increased the expression of flowering genes which ultimately led to overcome dormancy.
\end{abstract}

Keywords: Anthesis, Dormancy, Expression, Flower, FT, Gene, Induction, Initiation, Persian walnut, TFL1

\section{Background}

Flowering is considered as an important parameter with respect to crop yield and avoid of late-spring frost $[1,2]$. In addition to the genetic network controlling flower development, there are a number of much less studied

\footnotetext{
* Correspondence: saadat.sarikhani@ut.ac.ir; kvahdati@ut.ac.ir

${ }^{4}$ Department of Horticulture, College of Aburaihan, University of Tehran, Tehran, Iran

${ }^{5}$ Department of Horticulture, College of Aburaihan, University of Tehran, Tehran, Iran

Full list of author information is available at the end of the article
}

metabolites and exogenous factors such as chilling requirement that may influence the transduction to flowering as well as flower anthesis [3]. Knowledge about flowering genes of fruit trees is scarce. On the other hand, some aspects of flowering in fruit trees such as juvenile and long generation time are the especial challenges to study flower development genes in fruit trees [1]. In addition, flower induction and initiation of many fruit trees occurs in the previous year and therefore the vegetative growth, flowers, and fruits of the

(c) The Author(s). 2020 Open Access This article is licensed under a Creative Commons Attribution 4.0 International License, which permits use, sharing, adaptation, distribution and reproduction in any medium or format, as long as you give appropriate credit to the original author(s) and the source, provide a link to the Creative Commons licence, and indicate if changes were made. The images or other third party material in this article are included in the article's Creative Commons licence, unless indicated otherwise in a credit line to the material. If material is not included in the article's Creative Commons licence and your intended use is not permitted by statutory regulation or exceeds the permitted use, you will need to obtain permission directly from the copyright holder. To view a copy of this licence, visit http://creativecommons.org/licenses/by/4.0/. The Creative Commons Public Domain Dedication waiver (http://creativecommons.org/publicdomain/zero/1.0/) applies to the data made available in this article, unless otherwise stated in a credit line to the data. 
previous year have significant effects on flowering in the current year [4].

In order to understand the flowering phenomenon of perennial plants, physiologists first studied flowering of Arabidopsis thaliana as a model plant [5]. The $A B C$ model was the primary model in the flower development proposed for Arabidopsis thaliana [6] and Antirrhinum majus [7]. This model postulates the function of three different classes of gene activities $\mathrm{A}, \mathrm{B}$ and $\mathrm{C}$ which together determine floral organ identity $[5,8]$. The $A B C$ model has been approved in a wide range of higher plants and many molecular studies largely support this model $[9,10]$. The floral meristem identity genes induce the different floral organs including sepals, petals, stamens, and carpels according to the $A B C$ model [11].

Previous studies indicated that FLOWERING LOCUS $T(F T)$ is a key gene in plant flowering especially in response to photoperiod. FT as an upstream gene promotes floral meristem identity by activating other flowering genes [12]. In addition to $F T$ gene, SOC1 (SUPRESSOR OF OVEREXPRESSION OF CONSTANS 1), CAL (CAULIFLOWER) and LFY (LEAFY) are other key genes involved in floral meristem identity and flowering time. The SOC1 is one of the main genes required for the timely activation of $\mathrm{B}$ and $\mathrm{C}$ floral organ identity genes [13]. The CAL as a MADS-box gene is closely related to APETALA1 (AP1), and encodes proteins involved in the floral meristems formation [14]. Like $C A L$, $L E A F Y(L F Y)$ is a floral meristem identity gene which is an important element of the transition from the vegetative to the reproductive phase [15]. In contrast, TFL1 is a key gene involved in flowering time and development having reverse function of the above-mentioned genes. In other words, TFL1 gene represses flowering and has a key role in bud dormancy during the winter [16].

Although, the molecular aspect of flower development in Arabidopsis has been widely studied in recent years, the expression pattern of major genes involved in flower development of fruit trees such as walnut are almost obscure. Fruit trees have a long vegetative phase before reproductive phase and the flowering cycle repeats for successive years [17]. In temperate deciduous species, budbreak and flowering is dependent on sufficient winter chilling [18]. Currently, researchers are widely using transcriptomics and other powerful genetic tools based on next generation sequencing to study complex gene networks involved in flowering. These studies provide a comprehensive understanding of the gene network involved in flowering of model and nonmodel plants $[19,20]$.

Persian walnut (Juglans regia L.) is a major nut crop in the world which originated from old Persia. Iran as one of the main origin and distribution centers of walnut has a significant share of the worldwide walnut industry and is one of the leading countries in the walnut production $[21,22]$. Due to limited information on the precise timing of the different flower development stages in walnut as well as the gene network involved in walnut flowering, studying the expression pattern of major genes involved in flowering and its relation to different stages of walnut flower development can enhance our knowledge for future studies. The objective of the current study was to investigate the expression of some flowering genes during walnut flower development and to understand the pattern of expression of these genes at different flower development stages (from flower induction to anthesis) during the growing season and winter dormancy.

\section{Results}

The results showed that walnut flower induction occurred in early June in two consecutive years under the conditions prevailed in Shahmirzad, Iran. At this stage, the buds were deformed from a sharp tip to a flat and dome-shape buds. The buds did not show any significant change during summer. Nevertheless, flower initiation was observed in late-September and the pedicles and vascular bundles were visible by optical microscope. During winter dormancy, walnut flower buds increased in weight and entered maturation. After meeting chilling and heat requirement, the bud development started at the end of March. Flower anthesis of walnut trees (cv. Chandler) occurred from mid-April to early-May under Shahmirzad condition (Additional file 2).

There were significant differences among the expression of several genes, i.e. FT, SOC1, CAL, FLY and TFL1, in walnut buds at different times of the year. Figure 1 and Additional file 3 show the BOXPLOT and fold change diagrams, respectively, pertaining to the studied genes in the walnut buds. Results showed that the expression of the FT gene increased in buds from late March. This upward trend lasted until late April (coincided with flower differentiation and anthesis). Then, the FT gene exhibited its expression peak in late May to mid-June (coincided with flower induction), and thereafter the expression declined in the buds. From mid-August onwards, this gene was not expressed in the terminal buds of walnuts (Fig. 1a).

With regard to the SOC1 gene, its expression began late-March (during flower differentiation) and gradually acquired high levels by end of the growth season. The highest level of its expression was recorded in mid-June when the onset of flowering and the induction of flowering were observed in walnuts. The level of its relative expression gradually decreased thereafter, and fell to almost the reference level (8th of June) at the end of the growing season (Fig. 1b).

$C A L$ is a floral meristem identity gene that has a very close relationship with the APETALA1 gene (AP1). We 


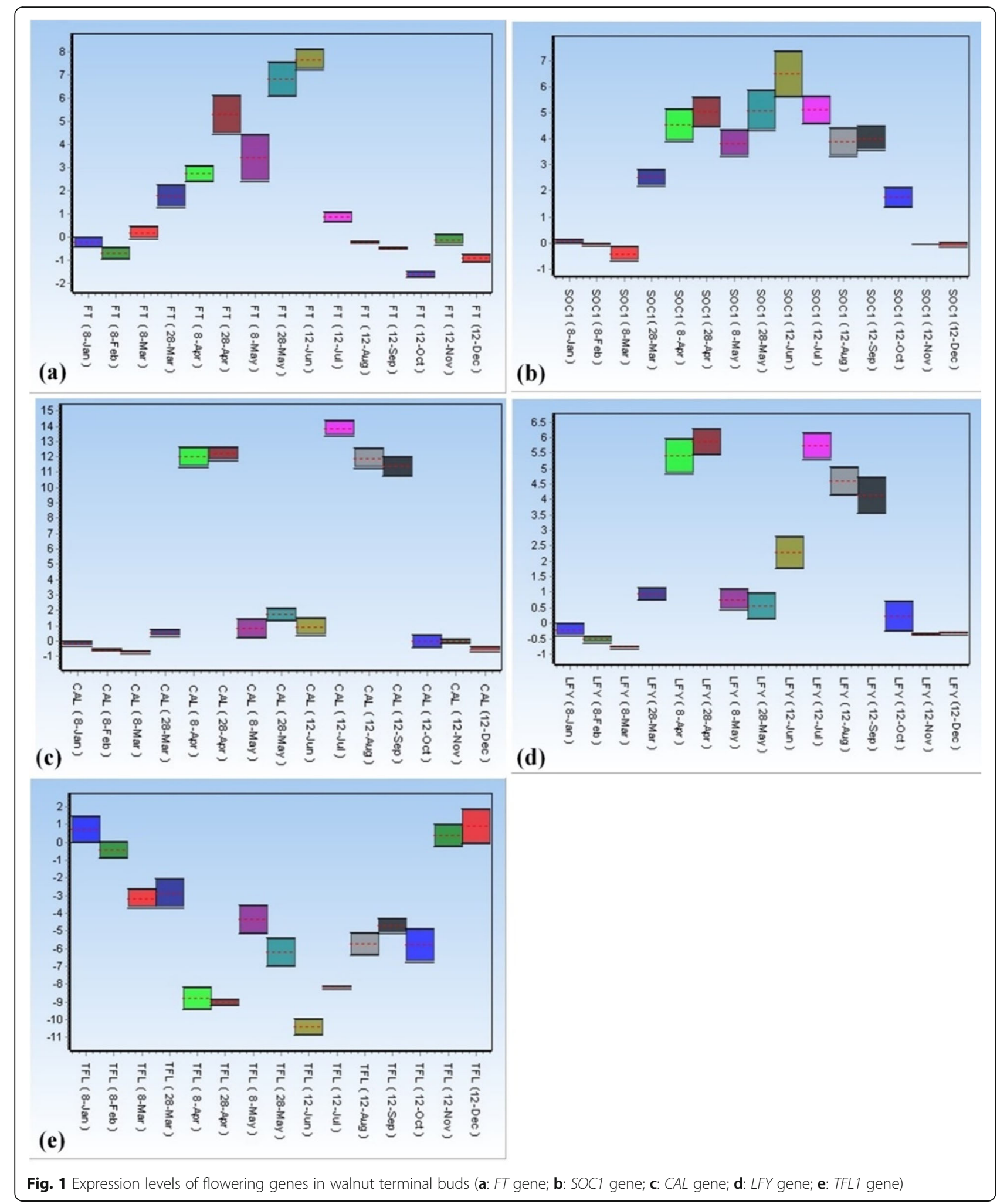

observed that the expression of the $C A L$ gene increased suddenly from early April. This increase was boosted from mid-April until the start of flowering. Then, a sharp decrease in the expression of the $C A L$ gene was observed. A subsequent significant increase in its expression was observed in mid-July until mid-September. Nonetheless, this gene was not expressed from harvest time (early-October) until the start of the next growing 
season (late-March) (Fig. 1c). The expression analysis of the $L F Y$ gene generated results that were almost similar to the $C A L$ gene. However, the fold change level of $L F Y$ expression was generally lower than that of the $C A L$ gene. Like the $C A L$ gene, the expression of the $L F Y$ gene exhibited two major peaks during the growth season. The first peak was observed at the beginning of the growing season (late-March). The second peak occurred concurrently with the onset of flowering and with the induction of flowering in mid-late summer. From harvest time (early-October) onwards, the expression of $L F Y$ reached to the reference level (Fig. 1d).

As a protein, TFL1 is structurally similar to FT but with different functions. A decrease in the presence of TFL1 can accelerate the induction of flowering. Realtime PCR analysis showed that the TFL1 gene expressed at the end of the walnut growth season and its expression peaked at the beginning of January. The high level of its expression was maintained during the first month of the year and until the beginning of March. Nonetheless, the expression of TFL1 decreased with the onset of growth season and almost minimized at the time of flowering. Then, its expression increased in May, but again stopped at the beginning of July, parallel to the onset of flower induction (Fig. 1e).

The relationship between expression of genes herein was determined according to the Spearman correlation coefficient (GenEx software). Based on the results, the highest correlation was observed between $C A L$ and $L F Y$ genes $(\mathrm{r}=0.96)$. The $S O C 1$ gene correlated strongly with the $C A L$ gene $(\mathrm{r}=0.86)$ and the $L F Y$ gene $(\mathrm{r}=0.86)$. On the other hand, the TFL1 gene showed a negative correlation with the other genes (Table 1). Figure 2 shows the heat map and cluster analysis of the genes expressed in the terminal buds of the Persian walnut trees. Accordingly, the TFL1 gene was classified in a separate group, which is due to its inhibitory effect on the flowering of walnut. The $C A L$ and $S O C 1$ genes were responsible for flowering, hence they placed in one subgroup, whereas the two $L F Y$ and $F T$ genes were clustered in another subgroup (Fig. 2). Figure 3 shows a proposed overview of the relationships among flowering genes involved in the flowering-time pathways of walnut based on Arabidopsis flowering pathway. By evaluating the interactions between the genes involved in flowering, it can be

Table 1 Spearman correlation between the flowering genes expression in walnut buds

\begin{tabular}{llllll}
\hline & $F T$ & SOC1 & CAL & LFY & TFL1 \\
\hline SOC1 & 0.624 & 1 & & & \\
CAL & 0.442 & $0.865^{* *}$ & 1 & & \\
LFY & 0.447 & $0.858^{* *}$ & $0.960^{* *}$ & 1 & \\
TFL1 & -0.633 & -0.786 & -0.678 & -0.737 & 1 \\
\hline
\end{tabular}

concluded that the end of winter (mid-March) is a time when the TFL1 gene shows lower levels of expression, while higher levels of expression by the FT and SOC1 genes were observed. Based on previous studies, it was expected that an increase in the expression of the $F T$ gene would stimulate the expression of downstream genes involved in flowering. This increases the expression of $L F Y$ and $C A L$ genes, whereby the differentiation of flower buds ensues.

Based on our results, after flowering, there was a decrease in the expression of the FT gene, followed by a decrease in the amounts of other flowering stimulators, whereas an increase in the expression level of TFL1 gene was observed. However, this trend was completely reversed after a period of about one month, which was associated with an increase in the expression of $F T$ and a reduction in the expression of TFL1. In early June, the expression of $F T$ and $S O C 1$ genes increased, whereas the expression of the TFL1 gene decreased. This balance caused the onset of flowering in buds, thereby preparing them for the following year. Following the increase in the expression of the $F T$ gene, the expression level of $L F Y$ and $C A L$ genes also increased, thereby leading to the flower induction in late summer. As autumn began, the expression of genes involved in flowering decreased, while the expression of TFL1 increased. This trend continued throughout autumn, which was parallel to meeting the chilling requirement of buds. During autumn and winter, as the TFL1 gene maintained a high level of expression, the flowering buds of walnut remained dormant. Ultimately, as the chilling requirement was met, the TFL1 gene was expressed at a lower level, thereby making the buds ready for differentiation (Fig. 4).

\section{Discussion}

Flowering is a complex event regulated by interactions between external and internal signals. The external flowering signals such as low temperature and light stimulate a network of internal transcription regulators that control flowering [23]. Our knowledge about the time of the different reproductive development stages is very important to ensure successful production and improve orchard management [24]. Previous studies indicated that walnut flower induction occurs a few weeks after the full bloom stage [5, 25-27]. Also, they state that flower initiation is in the late summer [24, 28]. Our results showed that walnut flower development like other fruit trees is divided into four stages including flower induction, initiation, differentiation and anthesis [5]. Walnut flower induction and initiation in the studied area (Shahmirzad, Semnan, Iran) occurred in early June and late summer, respectively. In general, walnut flower development (from induction to anthesis) lasts from June to May of the following year [29]. 


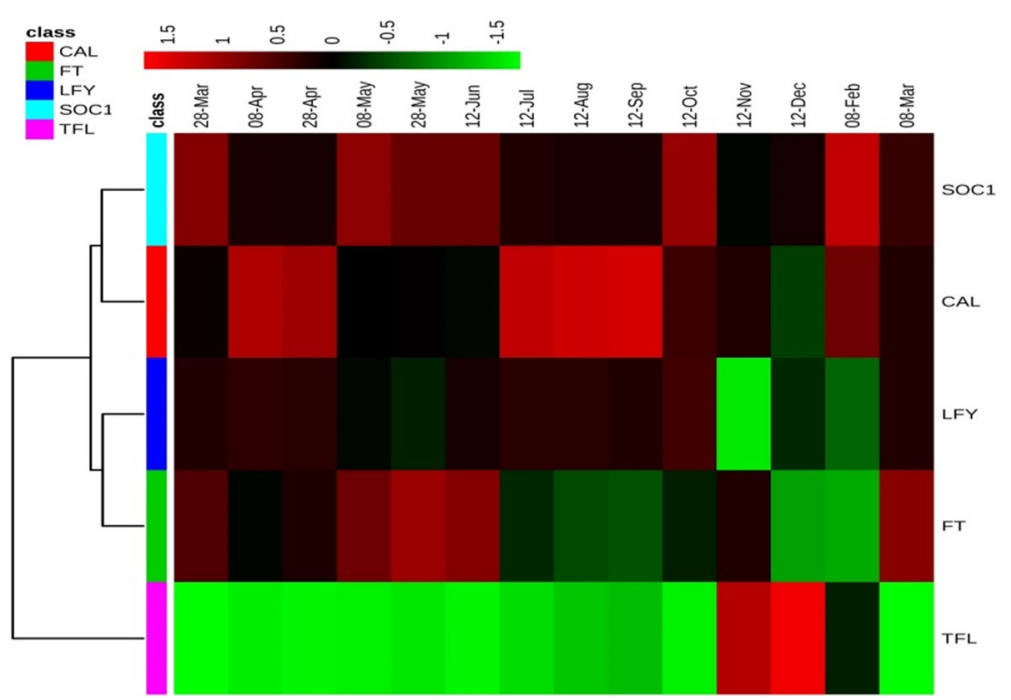

Fig. 2 Heatmap cluster of the studied gene expression involved in walnut flowering

Flowering like other physiological process regulated by a large and complex gene networks. Certainly, studying the complete genome is necessary to gain a comprehensive understanding of the gene network involved in flowering. Utilizing powerful genetic tools based on next generation sequencing are an effective strategy for studying complex gene networks in flowering $[19,20]$.

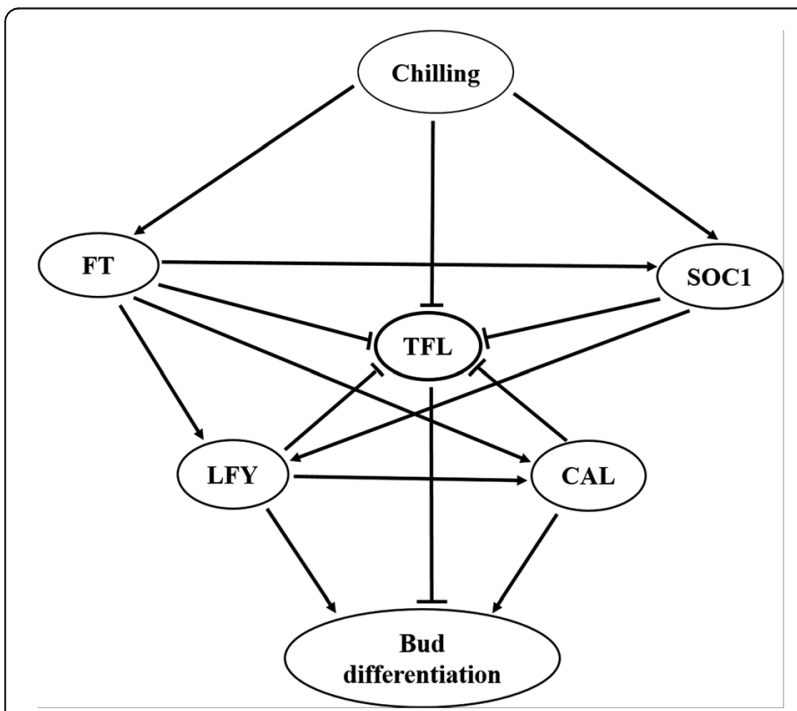

Fig. 3 A simplified model of pathway controlling walnut flowering time based on Arabidopsis flowering pathway. The scheme shows the known genes involved in flowering regulation and the interactions between them and chilling requirement. $\mathrm{FT}$ and $\mathrm{SOC1}$ overexpress and encode proteins that activate the floral meristem identity genes such as $L F Y$ and CAL which convert the vegetative meristem to floral fate. TFL1 as a flowering inhibitor gene has overexpression during the bud dormancy and its expression was decreased by meeting chilling requirement
Nevertheless, investigating the major genes (like FT, $S O C 1, T F L 1, C A L$, etc.) involved in flower development of plants can also improve our knowledge on the molecular mechanisms of flowering, especially in plants that have not been studied so far. The role of the $F T$ gene in regulation of flowering has been identified in numerous species [19, 30-32]. Previous studies showed that FT gene promotes the transition to flowering and reproductive development [33, 34]. The results of the current study showed that the expression of the $F T$ gene increased in three stages including before breaking of bud dormancy, from late March to late April and from late May to mid-June. Comparing the results of anatomical study of walnut flower development in Shahmirzad condition with the results of $F T$ gene expression showed that $F T$ gene was expressed slightly before flower differentiation. Also, the expression of FT gene was increased before budbreak and flower induction [33, 35, 36]. Based on our results, $F T$ gene was found to be suppressed during bud dormancy in winter which indicated the role of $F T$ gene in interacting with other genes in bud dormancy. Previous studies reported that $F T$ plays an important role in winter dormancy especially ecodormancy in plants such as Populus sp. [37, 38] and grape [39].

The results showed that the expression of SOC1 increased during flowering and flowering induction. The expression pattern was significant at the end of bud dormancy. Lee et al. [40] reported that SOC1 expression directly correlates with LEAFY expression and regulates the induction of flowering in flower development process. In Arabidopsis, the SOC1 gene from the MADS-box has been proven to play an important role in integrating the flowering pathways. These genes are 


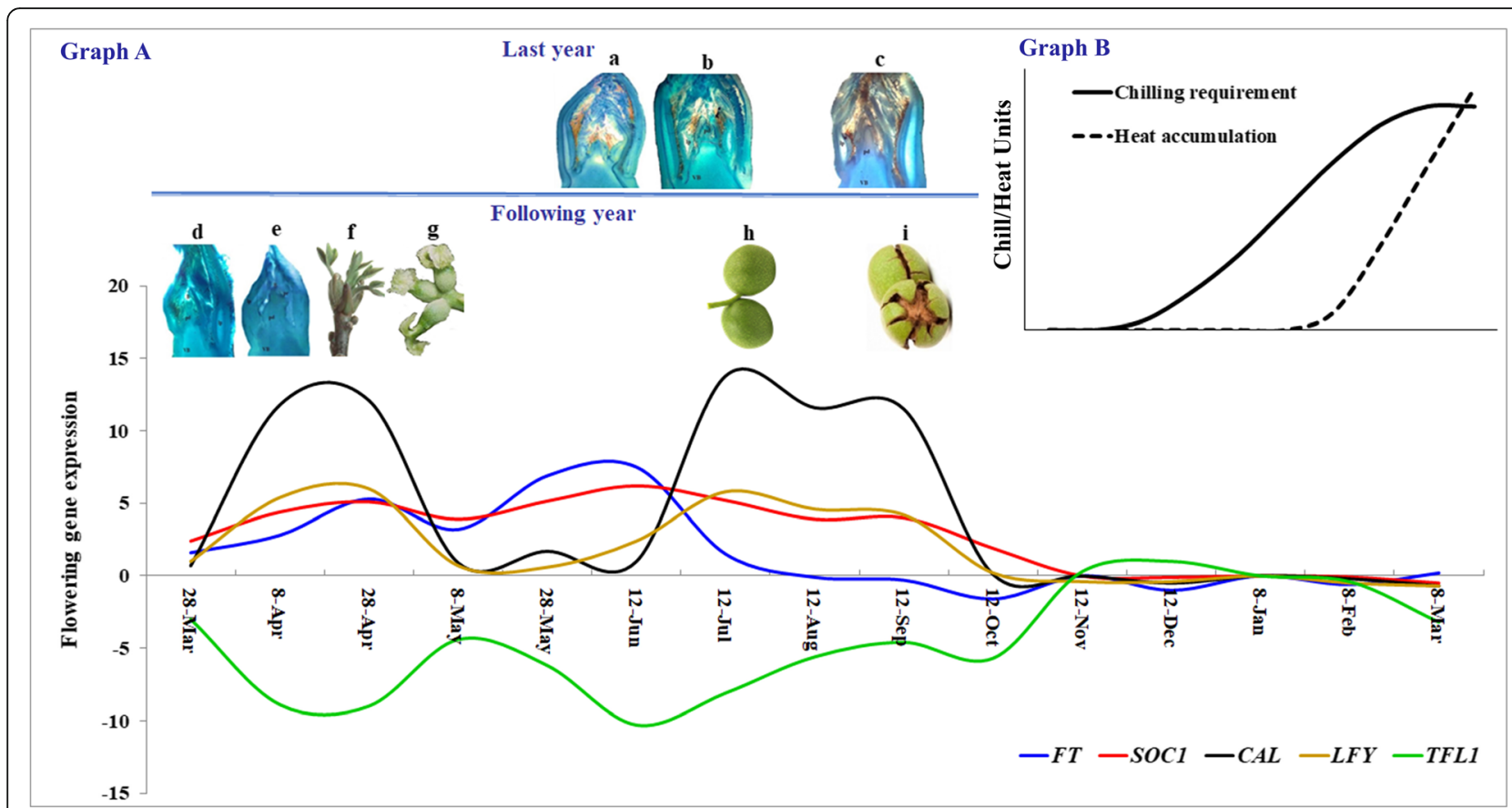

Fig. 4 A general pattern of flowering genes expression and the date of different stages of flower development in walnut; flower induction (a, b) and initiation (c) occurred in the summer of last year. Flower differentiation $(\mathbf{d}, \mathbf{e})$ and anthesis $(\mathbf{f}, \mathbf{g})$ were observed in late March to early May of the same year. Harvest date (i) was from mid to late September. The graph C shows chilling and heat requirement of walnut trees cv. Chandler. An adequate winter chill and subsequent heat accumulation increase expression of flowering gene and release dormancy

critical for determining the exact flowering time and supporting the maximum fertility. Furthermore, SOC1 as a AGAMOUS-LIKE 20 or AGL20, independently and by the aid of two other groups, is reported as a positive flowering regulator $[41,42]$. The $F T$ and $S O C 1$ are likely representing the integration points of flowering pathways that enhance the expression of floral meristem identity genes [42-44]. A study on apple trees showed that the transcription of $M d S O C 1$ was activated when the flower was induced [25]. In Arabidopsis, $F T$ activates the expression of SOC1 [45]. According to the results of this study, the $F T$ gene in the walnut is likely responsible for the activation of SOC1. Increasing the expression of the $S O C 1$ gene at the end of dormancy may be due to an increase in expression of the $F T$ or it may be independently involved in dormancy release. This conclusion is based on some results in Arabidopsis which indicated that the SOC1 gene is involved in the transduction of chilling signals [46] .

The $C A L$ gene is a transcription factor that probably requlates the flora meristem identity genes in coordination with the APETALA1, FRUITFULL and LEAFY genes. This gene is the orthologous gene of $A P 1$ and the MADS-box genes. Our results indicated that the expression of $C A L$ significantly increased at the bud break and flowering time. It might be due to the effects of this gene on the identification of flower organs in nuts. Ferrandiz et al. [47] determined that FUL, $A P 1$ and $C A L$ control the formation of inflorescences by affecting the expression of $L F Y$ and TFL1, as well as their relative activity. The $L F Y$ protein directly activates the $A P 1$ protein and its homologous protein $(C A L)$ in the flowers meristem $[48,49]$. AP1 B (Homologous CAL gene) is activated via $F T$ [50]. The $C A L$ and $F T$ suppress the expression of TFL1 in meristem.

TERMINAL FLOWER1 (TFL1) is a homologous protein to $F T$ but has a different function in Arabidopsis $[51,52]$. Increasing the expression of $A P 1$ in Arabidopsis decreased the expression of TFL1, indicating the activity of $A P 1$ as a suppressor of TFL1 [53, 54]. Our results on walnuts also showed that there was a negative correlation between the CAL and TFL1 gene. In other words, the $C A L$ acts as a TFL1 suppressor in the walnut. Given that $L F Y, A P 1$, and $C A L$ are transcription factors, they are possibly directly interacting with cis-elements in the TFL1 promoter [55]. Many studies on $L F Y$ have been conducted as a key control gene for flowering. In other words, the effective expression of $L F Y$ for the conversion of vegetative buds into the flowering ones is necessary, which indicates that this gene is a critical factor for the identification of flowers meristem [56, 57]. The $L F Y$ protein directly activates the AP1 protein and its homologous $C A L$ in the meristems [48]. He et al. [58] identified the $J r L F Y$ gene from Persian walnut. This gene consists 
of three exons and two introns. The sequencing of this gene is expected to form a polypeptide with 385 amino acids and has a conserved sequence within its Cterminal. They reported that the sequence of $L F Y$ protein in walnut is very similar to the one found in chestnut and hickory. The initiation of flowering and the transformation of the identity of floral meristem in Arabidopsis is largely dependent on the endogenous and environmental stimuli that ultimately cause the gene expression of $L F Y$ ( $L E A F Y)$ and flowering conditions $[59,60]$. The results of the present study indicated that the $L F Y$ expression increased before flowering and flowering time in walnut, and at other times, no significant levels of its expression were observed. Expression analysis of $F T, C A L, S O C 1, L F Y$ and TFL1 showed that at the end of the dormancy, the TFL1 expression decreased while the $F T$ and $S O C 1$ expression increased. At the end of the dormancy, the expression of the $F T$ increased, which triggered the activation of the SOC1 [45], that consequently led to expression of downstream genes, such as $L F Y$ and $C A L$. The expression of these genes significantly increased during the flower bud differentiation, which led to the flowering of walnut. After flowering, the expression $F T$ and other flowering stimuli genes were decreased, but the expression of TFL1 increased. In the following, the expression of the TFL1 was reduced by increasing the expression of $F T$ and other flowering stimuli genes which led to the flowering induction in walnut [42-44].

\section{Conclusion}

$F T$ gene is a primary stimulus gene in walnut flowering. The expression of $F T$ gene not only increases in flower anthesis phase, but also increases in flower induction phase. SOC1 is similar to $F T$ showed overexpression in flower induction and anthesis stages. In contrast to $F T$ gene, SOC1 gene had a high level of expression in other times throughout growth season. The $L F Y$ and $C A L$ genes are floral meristem identity genes which are activated by upstream genes such as $F T$ and SOC1 genes. TFL1 is a flowering inhibitor gene in walnut which is overexpressed during the bud dormancy stage and chilling requirement reduces TFL1 gene expression and overcome bud dormancy. In general, the interaction of flowering promoting genes such as FT and SOC1 with flowering inhibiting genes including the TFL1 gene modulate flowering transition and development including flower induction, initiation, differentiation and anthesis as well as bud dormancy of walnut trees. The present study provides an initial insight on the timing of the different stages of flower development in walnut and some major genes involved in this process. Definitely, a wide range of genes and gene networks as well as various pathways involved in walnut flowering which can be considered in the future. Based on the obtained results from gene expression as well as anatomical and phenological studies, the exact time of flower and fruit development stages of walnut from flowering to harvesting time was determined. Due to these results, fertilizer, irrigation and other orchard management factors can be adjusted.

\section{Methods \\ Plant materials}

This study was carried out in Shahmirzad Agro-Industry Company in Shahmirzad, Semnan Province, Iran. Shahmirzad (Latitude: $35.7729^{\circ} \mathrm{N}$, Longitude: $53.3277^{\circ} \mathrm{E}$, Altitude: $\approx 2050 \mathrm{~m}$ ) which is located in a mountainous region on the southern slopes of the Alborz mountains, has a temperate climate with cool summers and cold winters. The plant materials were 15-years-old ownrooted Persian walnut trees (Juglans regia L. cv. Chandler) planted in a density of $5 \mathrm{~m} \times 7 \mathrm{~m}$. The studied walnut trees were produced by a Tissue Culture Laboratory namely RANA Agro-Industry Corporation, Iran. The most authentic material of 'Chandler' exists at University of California, Davis and does not have any voucher specimen and deposition number.

\section{Determining the time of flower induction, initiation and differentiation}

Before studying the molecular mechanism of flower development, it was necessary to determine the time of different flower development stage (induction, initiation and differentiation) under the climate condition of Shahmirzad, Semnan. For this purpose, the anatomy of female flower bud was studied in three consecutive years (2014-2016). The buds were sampled throughout the year with 14-day intervals and were fixed overnight in fixation solution (including 10\% formaldehyde $+5 \%$ acetic acid $+50 \%$ ethanol). The buds were cut vertically with a sharp razor and were stained with methylene blue and carmine [61]. The microscopy technique (Nikon Eclipse E200, Japan) was used for the determination of flower development stage.

\section{Assessment of chilling and heat requirement}

Assessment of chilling and heat requirement of the studied walnut trees (Juglans regia L. cv. Chandler) was not one of the main objectives of this study. But, to better understand the expression patterns of the studied genes and to determine the precise time to meet chilling and heat requirement as well as release of bud dormancy, the chilling and heat requirement of walnut trees (cv. Chandler) were assessed. In the first step, we used oneyear-old twigs with a terminal bud and catkin to determine chilling and heat requirement based on Utah and Growing Degree Hours $\left(\mathrm{GDH}^{\circ}\right)$ models, respectively [62]. 
Six chilling treatments $(650,800,950,1100,1250$ and 1400 Utah Chilling Unit (CU)) and three replications were considered [3]. The results showed that the chilling requirement of terminal bud and catkin were 950-1100 and 800-950 CU, respectively. For evaluation heat accumulation, the studied twigs which received 950-1100 chilling unit, were placed in the greenhouse condition with a natural photoperiod and temperature between 16 and $23^{\circ} \mathrm{C}$. $\mathrm{GDH}^{\circ}$ is considered as a degree upper threshold temperature for one hour. The heat requirement of walnut tree cv. Chandler was $11,832 \mathrm{GDH}$ for terminal buds and 12,180 GDH for catkins.

In order to ensure the results of laboratory studies, chilling requirement and heat accumulation of the studied walnut trees were also evaluated based on Utah and Growing Degree Hours $\left(\mathrm{GDH}^{\circ}\right)$ models, respectively [3]. Given that the phenological data of the studied walnut trees were available for 5 consecutive years (2013-2017), the 5-years meteorological data were used to evaluate chilling requirement and heat accumulation. Phenological data were evaluated based on IPGRI descriptor. $\mathrm{CU}$ and GDH were gathered from the IRIMO (Iran Meteorological Organization) website (http://www.irimo.ir) for the nearest synoptic station to the studied orchard. The data obtained from this section confirm the results of the laboratory study.

\section{RNA extraction and CDNA synthesis}

In order to study the pattern of gene expression, 12 walnut trees cv. Chandler ( 3 replications and 4 trees in each replication) with the same age, trunk diameter and growth condition were selected. Total RNA was extracted from flowering buds throughout two consecutive years with 14-day intervals when the samples were prepared for anatomical study (2016-2017). RNA extraction was conducted using phenol saturated method described by Ghawana et al. (2011). To prepare extraction buffer, saturated phenol was added to sodium dodecyl sulphate $(0.1 \% \mathrm{w} / \mathrm{v})$, sodium acetate $(0.32 \mathrm{Mw} / \mathrm{v})$ and EDTA $(0.01 \mathrm{M})$. Approximately $0.1 \mathrm{~g}$ of bud sample was homogenized using a mortar and pestle to a fine powder in liquid nitrogen. A volume of $900 \mu \mathrm{l}$ of extraction buffer, $100 \mu \mathrm{l}$ of PVP solution and $5 \mu \mathrm{l}$ of $\beta$-mercaptoethanol was added rapidly to the prepared powder and then was shaken vigorously. Then, $800 \mu \mathrm{l}$ of DEPC-treated water was added and mixed by homogenizing for $5 \mathrm{~min}$ at room temperature. Chloroform $(200 \mu \mathrm{l})$ was added to each tube and vortexed briefly $(<10 \mathrm{~s})$ and left for 10 min at room temperature.

The prepared samples were centrifuged at 13,000 rpm for $10 \mathrm{~min}$ at $4{ }^{\circ} \mathrm{C}$ and the upper aqueous phase was transferred into fresh tubes. Then, $600 \mu \mathrm{l}$ of isopropanol was added to tubes and vortexed briefly $(<10 \mathrm{~s})$ and left for $10 \mathrm{~min}$ at room temperature. After that, the tubes were centrifuged at $13,000 \mathrm{rpm}$ for $10 \mathrm{~min}$ at $4{ }^{\circ} \mathrm{C}$ and the supernatants were discarded. RNA pellet was washed with $70 \%$ ethanol and dissolved in 20 to $50 \mu \mathrm{l}$ of DEPCtreated water. Quality of RNA was evaluated using 1\% agarose gel. Also, purity and concentration of RNA was assessed by determining the absorbance of the sample at 260 and $280 \mathrm{~nm}$ using a spectrophotometer (PerkinElmer, Lambda 25, USA). Before cDNA synthesis, RNA was treated with RQ1 RNase-free DNase (Jena Bioscience, Germany). The first strand cDNA was synthesized by Easy cDNA synthesis kit (Pars Tous Biotechnology, Iran). PCR was performed in a $20 \mu \mathrm{l}$ reaction containing $2 \mu \mathrm{l}$ of cDNA, $0.6 \mathrm{mM}$ dNTP, $1 \mu \mathrm{l}$ of control primer, $1 \mathrm{X}$ reaction buffer, $0.7 \mathrm{mM} \mathrm{MgCl} 2$ and $1.5 \mathrm{U}$ of Taq DNA polymerase.

\section{Primer design and gene-expression analysis by real-time PCR}

The candidate genes in the current study were $F T, C A L$, SOC1, LFY and TFL1. The sequence of CAL and $L F Y$ genes in Juglans regia $\mathrm{L}$. is available at NCBI website. The sequence of FT (Malus domestica; GenBank ID: DQ535887), SOC1 (Vitis vinifera; GenBank ID: GU133633) and TFL1 (Malus domestica; GenBank ID: NM_001293958) genes was used for a BLAST search in the walnut genome (https://www.ncbi.nlm.nih.gov/genome/17683). The sequences with the highest homology with the query sequences were used as templates to design primers. Therefore, the specific primers were designed for FT, CAL, SOC1, LFY and TFL1 genes using Vector NTI and Oligo 3 software (Table 2). The purity and specificity of the designed primers were tested by PCR (Additional file 1).

To study gene expression, real-time PCR was conducted using the LightCycler 96 (Roche, Germany) with

Table 2 Annotation, sequences and accession numbers of primers used for gene isolation and quantitative real-time PCR analyzes

\begin{tabular}{lll}
\hline Annotation & Accession & 5' $^{\prime}$ - primer- 3' \\
\hline FT-F & DQ535887 & GGTTGATGTAGGCGTGGTGAC \\
FT- $R$ & & CCGCTGTTGTTGTGGAATATC \\
CAL-F & XM_018962972 & $\begin{array}{l}\text { CTGTGTGATGCTGAGGTCGG } \\
\text { GTGACTAGCTTCGCCTCTGC }\end{array}$ \\
LFY-F & & CTTCCATCACTACGAGCAGAGC \\
LFY-R & JF520778 & CTCCAGCCTCTTCGATACC \\
SOC1-F & GU133633 & TCTTTGGATGCCGAGGTG \\
SOC1-R & & TTGTGATGGTTGAGCGTC \\
TFL1-F & NM_001293958 & TCACACTGGTCGAGACTGACC \\
TFL1-R & & ACCTCCCTTCCTAATGTGGTC \\
ACTIN-F & XM_019003276 & GGATGAGCAAGGAGATTACAGC \\
ACTIN-R & & TTGCGATCCACATCTGTTGG \\
\hline
\end{tabular}


the SYBR Green real-time PCR Master Mix. Real-time quantification was performed in a reaction mix containing $2 \mu \mathrm{l} \mathrm{cDNA}, 0.2 \mu \mathrm{M}$ gene-specific forward and reverse primers, 1X SYBER Green master mix in a final $20 \mu \mathrm{l}$ reaction. Walnut actin gene (forward primer sequence: 5 'GGATGAGCAAGGAGATTACAGC-3', and reverse primer sequence: 5' - TTGCGATCCACATCTGTTGG$3^{\prime}$ ) was used as the normalizer (Table 2). Real- time PCR cycling conditions were for 40 cycles of $15 \mathrm{~s}$ at $95^{\circ} \mathrm{C}, 30 \mathrm{~s}$ at the annealing temperature, $30 \mathrm{~s}$ at the extension at $72{ }^{\circ} \mathrm{C}$ with $5 \mathrm{~min}$ at $72{ }^{\circ} \mathrm{C}$ for final extension.

\section{Statistical analysis}

The data obtained from real-time PCR were analyzed by GenEx software. Samples taken at the beginning of the year (8th of January) were considered as the reference standard and the fold change gene expression were compared to this time.

\section{Supplementary information}

Supplementary information accompanies this paper at https://doi.org/10. 1186/s12870-020-02372-w.

Additional file 1. Agarose gel electrophoresis of PCR products of the designed primer involved in flowering including FT ( $\approx 130 \mathrm{bp}), \mathrm{CAL}(\approx 170$ bp), TFL1 ( $\approx 120$ bp), SOC1 ( $\approx 130$ bp), LFY ( $\approx 125$ bp) and Actin ( $\approx 140$ bp) genes.

Additional file 2. Different flowering and fruit development stages of walnut during in three consecutive years (2014-2016) (Blue line: last year; Green line: following year).

Additional file 3 Fold changes of $F T$ (a), SOCl (b), CAL (c), LFY (d) and TFL1 (e) gene expression identified by quantitative RT-PCR analysis.

Additional file 4. The raw data obtained from real-time PCR and raw data to determine chilling requirement.

\section{Abbreviations}

FT: FLOWERING LOCUS T; SOC1: SUPRESSOR OF OVEREXPRESSION OF CONSTANS 1; CAL: CAULIFLOWER; LFY: LEAFY; TFL1: TERMINAL FLOWER 1

\section{Acknowledgements}

We would like to thank Iran National Science Foundation (INSF), National Elite Foundation (NEF) and University of Tehran (UT) for their supports. We also would like to thank Shahmirzad Agro-Industry Company for supplying the plant materials.

\section{Authors' contributions}

$\mathrm{KV}$ led and coordinated the project. $\mathrm{KV}$ and MR designed the study. $\mathrm{KV}, \mathrm{AH}$, SS and HR performed the experiment and analyzed the obtained data. All authors made substantial contributions to interpretation of data as well as participate in drafting the manuscript. Also, all authors read and approved the final manuscript.

\section{Funding}

Not applicable.

\section{Availability of data and materials}

All data analyzed during this study are included in this published article and its supplementary information files.

Ethics approval and consent to participate Not applicable.
Consent for publication

Not applicable.

\section{Competing interests}

The authors declare that they have no competing interests. The last author is an associate editor of BMC Plant Biology. The last author had no role in the editorial process.

\section{Author details}

${ }^{1}$ Department of Horticulture, College of Aburaihan, University of Tehran, Tehran, Iran. ${ }^{2}$ Department of Horticultural Sciences, Faculty of Agriculture, Shiraz University, Shiraz, Iran. ${ }^{3}$ Department of Agronomy and Plant Breeding Sciences, College of Aburaihan, University of Tehran, Tehran, Iran.

${ }^{4}$ Department of Horticulture, College of Aburaihan, University of Tehran,

Tehran, Iran. ${ }^{5}$ Department of Horticulture, College of Aburaihan, University of Tehran, Tehran, Iran.

Received: 7 January 2020 Accepted: 30 March 2020

Published online: 03 April 2020

\section{References}

1. Mariana BI, Sina NC. Effect of climatic conditions on flowering of walnut genotypes in Romania. J Nuts. 2017;8(02):161-7.

2. TavakoliBanizi R, Imani A, Zeinalabedini M, Ebrahimi A, Piri S. Genetic mapping of blooming time in 'Marcona' $\times$ 'Fragness' population with using molecular markers. J Nuts. 2015:6(1):57-65.

3. Hassankhah A, Vahdati K, Rahemi M, Sarikhani KS. Persian walnut phenology: effect of chilling and heat requirements on budbreak and flowering date. Int J Hortic Sci Technol. 2017;4(2):259-71.

4. Wilkie JD, Sedgley M, Olesen TJ. Regulation of floral initiation in horticultural trees. J Exp Bot. 2008:59(12):3215-28.

5. Hanke M-V, Flachowsky H, Peil A, Hättasch C. No flower no fruit-genetic potentials to trigger flowering in fruit trees. Genes Genom Genet. 2007;1(1): $1-20$.

6. Haughn GW, Somerville CR. Genetic control of morphogenesis in Arabidopsis. Dev Genetics. 1988;9(2):73-89.

7. Schwarz-Sommer Z, Huijser P, Nacken W, Saedler H, Sommer H. Genetic control of flower development by homeotic genes in Antirrhinum majus. Sci. 1990;250(4983):931-6.

8. Jack T. Molecular and genetic mechanisms of floral control. Plant Cell. 2004; 16(suppl 1):S1-S17.

9. Irish V. The ABC model of floral development. Curr Biol. 2017;27(17):R88790.

10. Bowman JL, Smyth DR, Meyerowitz EM. The ABC model of flower development: then and now. Dev. 2012;139(22):4095-8.

11. Lee J, Lee IJ. Regulation and function of SOC1, a flowering pathway integrator. J Exp Bot. 2010;61(9):2247-54.

12. Andrés F, Romera-Branchat M, Martínez-Gallegos R, Patel V, Schneeberger K, Jang S, Altmüller J, Nürnberg P, Coupland G. Floral induction in Arabidopsis by FLOWERING LOCUS T requires direct repression of BLADE-ON-PETIOLE genes by the homeodomain protein PENNYWISE. Plant Physiol. 2015;169(3): 2187-99.

13. Liu C, Xi W, Shen L, Tan C, Yu H. Regulation of floral patterning by flowering time genes. Dev Cell. 2009;16(5):711-22.

14. Kempin SA, Savidge B, Yanofsky MF. Molecular basis of the cauliflower phenotype in Arabidopsis. Sci. 1995;267(5197):522-5.

15. Blázquez MA, Soowal LN, Lee I, Weigel D. LEAFY expression and flower initiation in Arabidopsis. Dev. 1997;124(19):3835-44.

16. Hanano S, Goto K. Arabidopsis TERMINAL FLOWER1 is involved in the regulation of flowering time and inflorescence development through transcriptional repression. Plant Cell. 2011;23(9):3172-84.

17. Dutta S, Biswas P, Chakraborty S, Mitra D, Pal A, Das M. Identification, characterization and gene expression analyses of important flowering genes related to photoperiodic pathway in bamboo. BMC Genomics. 2018;19(1): 190.

18. Rohde A, Bhalerao RP. Plant dormancy in the perennial context. Trends Plant Sci. 2007;12(5):217-23.

19. Wang S, Gao J, Xue J, Xue Y, Li D, Guan Y, Zhang X. De novo sequencing of tree peony (Paeonia suffruticosa) transcriptome to identify critical genes involved in flowering and floral organ development. BMC Genomics. 2019; 20(1):572. 
20. Li H, Li J, Dong Y, Hao H, Ling Z, Bai H, Wang H, Cui H, Shi L. Time-series transcriptome provides insights into the gene regulation network involved in the volatile terpenoid metabolism during the flower development of lavender. BMC Plant Biol. 2019;19(1):313.

21. Khorami SS, Arzani K, Karimzadeh G, Shojaeiyan A, Ligterink W. Genome size: a novel predictor of nut weight and nut size of walnut trees. HortScience. 2018;53(3):275-82

22. Mahmoodi R, Hassani D, Amiri ME, Jaffaraghaei M. Phenological and pomological characteristics of five promised walnut genotypes in Karaj. Iran J Nuts. 2016;7(01):1-8.

23. Tan FC, Swain SM. Genetics of flower initiation and development in annual and perennial plants. Physiol Plant. 2006;128(1):8-17.

24. Gao Y, Liu H, Dong N, Pei DJ. Temporal and spatial pattern of indole-3acetic acid occurrence during walnut pistillate flower bud differentiation as revealed by immunohistochemistry. J Am Soc Hortic Sci. 2012;137(5):283-9.

25. Hättasch C, Flachowsky H, Hanke M-V, Lehmann S, Gau A, Kapturska D. The switch to flowering: genes involved in floral induction of the apple cultivar 'Pinova' and the role of the flowering gene MdFT. Acta Hort. 2008:839:701-5

26. Lin X, Chow T, Chen H, Liu C, Chou S, Huang B, Kuo C, Wen C, Huang L, Fang W. Understanding bamboo flowering based on large-scale analysis of expressed sequence tags. Genet Mol Res. 2010;9(2):1085-93.

27. Muñoz-Fambuena N, Mesejo C, Carmen González-Mas M, Primo-Millo E, Agustí M, Iglesias DJ. Fruit regulates seasonal expression of flowering genes in alternate-bearing 'Moncada' mandarin. Ann Bot. 2011;108(3):511-9.

28. Li Y, Zhao Y, Yang K, Fang Y, Hou L. Studies on floral organ development process of precocious walnut (Juglans regia) by anatomia. Acta Hort Sinica. 2011;38(3):434-40.

29. Germain E, Prunet J, Garcin A. Le noyer. 1st ed. CTIFL Press. France: Centre Technique Interprofessionnel des Fruits et Légumes; 1999.

30. Mouradov A, Cremer F, Coupland G. Control of flowering time: interacting pathways as a basis for diversity. Plant Cell. 2002;14(suppl 1):S111-30.

31. Zhang H, Harry DE, Ma C, Yuceer C, Hsu C-Y, Vikram V, Shevchenko O, Etherington E, Strauss SHJ. Precocious flowering in trees: the FLOWERING LOCUS T gene as a research and breeding tool in Populus. J Exp Bot. 2010; 61(10):2549-60.

32. Adeyemo OS, Chavarriaga P, Tohme J, Fregene M, Davis SJ, Setter TL. Overexpression of Arabidopsis FLOWERING LOCUS T (FT) gene improves floral development in cassava (Manihot esculenta Crantz). PlosOne. 2017; 12(7):e0181460.

33. Wickland DP, Hanzawa Y. The FLOWERING LOCUS T/TERMINAL FLOWER 1 gene family: functional evolution and molecular mechanisms. Mol Plant. 2015;8(7):983-97.

34. Zeevaart JA. Leaf-produced floral signals. Curr Opin Plant Biol. 2008;11(5): 541-7.

35. Varkonyi-Gasic E, Moss S, Voogd C, Wang T, Putterill J, Hellens RP. Homologs of FT, CEN and FD respond to developmental and environmental signals affecting growth and flowering in the perennial vine kiwifruit. New Phytol. 2013;198(3):732-46.

36. Harig L, Beinecke FA, Oltmanns J, Muth J, Müller O, Rüping B, Twyman RM, Fischer R, Prüfer D, Noll GA. Proteins from the FLOWERING LOCUS T-like subclade of the PEBP family act antagonistically to regulate floral initiation in tobacco. Plant J. 2012;72(6):908-21.

37. Hsu C-Y, Adams JP, Kim H, No K, Ma C, Strauss SH, Drnevich J, Vandervelde L, Ellis JD, Rice BM. FLOWERING LOCUS T duplication coordinates reproductive and vegetative growth in perennial poplar. Proc Natl Acad Sci U S A. 2011;108(26):10756-61.

38. Rinne PL, Welling A, Vahala J, Ripel L, Ruonala R, Kangasjärvi J, van der Schoot C. Chilling of dormant buds hyperinduces FLOWERING LOCUS T and recruits GA-inducible 1, 3- $\beta$-glucanases to reopen signal conduits and release dormancy in Populus. Plant Cell. 2011;23(1):130-46.

39. Pérez FJ, Kühn N, Vergara R. Expression analysis of phytochromes a, B and floral integrator genes during the entry and exit of grapevine-buds from endodormancy. J Plant Physiol. 2011;168(14):1659-66.

40. Lee J, Oh M, Park H, Lee I. SOC1 translocated to the nucleus by interaction with AGL24 directly regulates LEAFY. Plant J. 2008;55(5):832-43.

41. Borner R, Kampmann G, Chandler J, Gleißner R, Wisman E, Apel K, Melzer S. A MADS domain gene involved in the transition to flowering in Arabidopsis. Plant J. 2000;24(5):591-9.
42. Lee H, Suh S-S, Park E, Cho E, Ahn JH, Kim S-G, Lee JS, Kwon YM, Lee I. The AGAMOUS-LIKE 20 MADS domain protein integrates floral inductive pathways in Arabidopsis. Genes Dev. 2000;14(18):2366-76.

43. Onouchi H, Igeño MI, Périlleux C, Graves K, Coupland G. Mutagenesis of plants overexpressing CONSTANS demonstrates novel interactions among Arabidopsis flowering-time genes. Plant Cell. 2000;12(6):885-900.

44. Samach A, Onouchi H, Gold SE, Ditta GS, Schwarz-Sommer Z, Yanofsky MF, Coupland G. Distinct roles of CONSTANS target genes in reproductive development of Arabidopsis. Sci. 2000;288(5471):1613-6.

45. Yoo SK, Chung KS, Kim J, Lee JH, Hong SM, Yoo SJ, Yoo SY, Lee JS, Ahn JH. Constans activates suppressor of overexpression of constans 1 through flowering Locus T to promote flowering in Arabidopsis. J Plant Physiol. 2005;139(2):770-8.

46. Moon J, Suh SS, Lee H, Choi KR, Hong CB, Paek NC, Kim SG, Lee I. The SOC1 MADS-box gene integrates vernalization and gibberellin signals for flowering in Arabidopsis. Plant J. 2003;35(5):613-23.

47. Ferrándiz C, Gu Q, Martienssen R, Yanofsky MF. Redundant regulation of meristem identity and plant architecture by FRUITFULL, APETALA1 and CAULIFLOWER. Dev. 2000;127(4):725-34.

48. Wagner JA, Varga K, Járai Z, Kunos G. Mesenteric vasodilation mediated by endothelial anandamide receptors. J Hypertens. 1999;33(1):429-34.

49. William DA, Su Y, Smith MR, Lu M, Baldwin DA, Wagner D. Genomic identification of direct target genes of LEAFY. Proc Natl Acad Sci U S A. 2004;101(6):1775-80.

50. An H, Roussot C, Suárez-López $P$, Corbesier L, Vincent C, Piñeiro $M$, Hepworth S, Mouradov A, Justin S, Turnbull C. CONSTANS acts in the phloem to regulate a systemic signal that induces photoperiodic flowering of Arabidopsis. Dev. 2004;131(15):3615-26.

51. Shannon S, Meeks-Wagner DR. A mutation in the Arabidopsis TFL1 gene affects inflorescence meristem development. Plant Cell. 1991:3(9):877-92.

52. Bradley D, Ratcliffe $O$, Vincent $C$, Carpenter $R$, Coen E. Inflorescence commitment and architecture in Arabidopsis. Sci. 1997;275(5296):80-3.

53. Liljegren SJ, Gustafson-Brown C, Pinyopich A, Ditta GS, Yanofsky MF. Interactions among APETALA1, LEAFY, and TERMINAL FLOWER1 specify meristem fate. Plant Cell. 1999;11(6):1007-18.

54. Ratcliffe OJ, Bradley DJ, Coen ES. Separation of shoot and floral identity in Arabidopsis. Dev. 1999:126(6):1109-20.

55. Parcy F, Bomblies K, Weigel D. Interaction of LEAFY, AGAMOUS and TERMINAL FLOWER1 in maintaining floral meristem identity in Arabidopsis. Dev. 2002;129(10):2519-27.

56. Bowman JL, Alvarez J, Weigel D, Meyerowitz EM, Smyth DR. Control of flower development in Arabidopsis thaliana by APETALA1 and interacting genes. Dev. 1993;119(3):721-43.

57. Mandel MA, Yanofsky MF. A gene triggering flower formation in Arabidopsis. Nature. 1995;377(6549):522

58. He F, Wang H, Zhang ZJ. Molecular cloning and sequence analysis of an LFY homologous gene from Juglans regia L. Front Agri China. 2011;5(3):366.

59. Kobayashi Y, Weigel D. Development. Move on up, it's time for change-mobile signals controlling photoperiod-dependent flowering. Genes Dev. 2007:21(19):2371-84.

60. Blázquez MA, Ferrandiz C, Madueno F, Parcy F. How floral meristems are built. Plant Mol Biol. 2006;60(6):855-70.

61. Hassankhah A, Rahemi M, Mozafari MR, Vahdati K. Flower development in walnut: altering the flowering pattern by Gibberellic acid application. Not Bot Horti Agrobo Cluj-NA. 2018;46(2):700-6.

62. Richardson EA, Seeley SD, Walker DR. A model for estimating the completion of rest for Redhaven and Elberta peach trees. HortScience. 1974 9:331-2.

\section{Publisher's Note}

Springer Nature remains neutral with regard to jurisdictional claims in published maps and institutional affiliations. 